\title{
Teacher Attitudes to Language in University Bilingual Education
}

\author{
Francisco Rubio Cuenca \\ Univerdad de Cádiz \\ Pat Moore \\ Universidad Pablo de Olavide, Sevilla
}

Received: $10^{\text {th }}$ September $2017 /$ Accepted: $15^{\text {th }}$ February 2018

ISSN: $1697-7467$

\begin{abstract}
The main goal of this article is to explore the attitudes (opinions, beliefs, etc.) regarding 'language' of university teachers engaged in bilingual education. The context for this research is an on-going teacher development programme at the School of Engineering (Escuela Superior de Ingeniería) at the University of Cadiz. At this stage in our research, we are looking at teacher attitudes to language from three perspectives: to better understand what they think about language in their 'normal' i.e. Spanish/monolingual teaching; how they conceive of language per se in learning and how they feel about bilingual classrooms. Prior to their involvement in bilingual education, these teachers were likely encouraged to think of themselves as specialists in Áreas No Lingüisticas, but it would appear that they are in the process of reconceptualising both the roles of language in learning and the contributions that teachers can make. In the bilingual classrooms, most of their students are locals with limited language skills and the teachers favour an approach geared to developing both content and languages (L1 and L2) concurrently and perceive of themselves as both models and facilitators in the process. We interpret this as a good example of Internationalization at Home (IaH).
\end{abstract}

Keywords: teacher attitudes, L1/L2, language awareness, monolingual/bilingual classrooms, internationalization at home.

Actitudes de los docentes hacia el papel de la lengua en la educación bilingüe en la universidad

RESUMEN: El objetivo principal de este artículo es esbozar las actitudes (opiniones, creencias, etc.) respecto a la lengua del profesorado universitario participante en planes de enseñanza bilingüe. El contexto de esta investigación es un programa de formación permanente de docentes en la Escuela Superior de Ingeniería de la Universidad de Cádiz. En esta etapa de nuestra investigación, hemos analizado las actitudes de los docentes hacia el lenguaje desde tres perspectivas diferentes. Por un lado, comprender mejor lo que piensan sobre la lengua en su enseñanza "normal", es decir, español / monolingüe. Por otro lado, cómo conciben el papel de la lengua en sí en el proceso de aprendizaje. Por último, cuál es su opinión acerca de la enseñanza bilingüe. Antes de su participación en el programa de enseñanza bilingüe, estos docentes se consideraban 
a sí mismos especialistas en áreas no lingüísticas, pero tras un período extenso de formación, parecen inmersos en el proceso de re-conceptualización tanto del papel de la lengua en el aprendizaje como de las aportaciones que ellos mismos pueden hacer desde esta nueva perspectiva didáctica. En la clase bilingüe, la mayoría son estudiantes locales con capacidades lingüísticas limitadas, de ahí que la labor de los docentes se base en un enfoque orientado al desarrollo integrado de contenidos y lenguas (L1 y L2), y se perciban a sí mismos como modelos y facilitadores en el proceso de aprendizaje. Este es un buen ejemplo de internacionalización en casa.

Palabras clave: actitudes de los docentes, L1/L2, conciencia lingüística, clase monolingüe/ bilingüe, internacionalización en casa.

\section{InTRODUCTION}

The focus of this research is teacher attitudes, yet we set the scene by looking at language, students and demand. Language, from a medium of instruction perspective, is obviously a crucial factor in decision-making for prospective international students, be they short-term credit, or longer-term degree-seeking; incoming or outgoing. And a stereotypical view of internationalization would have it that, to attract international students (and staff), universities need to adopt English as a Lingua Franca via English-Medium Instruction (EMI).

That is certainly what has been happening in the North and West of Europe. Wächter and Maiworm (2014) found that $60.6 \%$ of the tertiary institutions in the Nordic countries in their study were offering English Taught Programmes (ETPs) compared to only 17.2\% in the South-West (France, Italy, Portugal and Spain). Considering that the local languages of the Nordic countries: Danish, Finnish, Icelandic, Norwegian and Swedish, are not widely spoken, coupled with the fact that English is already very present in these countries, there is a certain logicality in their adopting EMI to attract international students.

Spanish is a very widely-spoken language, both as L1 and L2. International students coming to Spain may well be doing so because of the language. Data from an Erasmus Student Network (ESN) Study (2014) found that students choosing countries where French, German, Italian and Spanish (the "Big Four" European Foreign Languages (FLs)) are spoken, are more likely to have chosen their country precisely because of the local language and are also more likely to report progress in that language after their stay. This was true of $68.3 \%$ of Erasmus students coming to Spain in the academic year 2013-14. Along the same lines, around $50 \%$ of longer-term degree-seeking international students in Spain are from Latin America and so already speak Spanish (Olivella Nadal, 2016).

Regarding credit-seeking undergraduates, it should be remembered that most are exchange students and Erasmus data (European Commission, 2015) confirms that Spain not only receives the most in-coming students; it also sends the most out-going. This means that internationalizing local/home students is also very important. This was recognised in the recent set of guidelines published by the Confederación de Rectores de las Universidades Españolas (CRUE) (2017), which actively promotes Internationalization at Home (IaH) as a key strategy. 


\section{Context}

The immediate context of this experience is the Plurilingual Education Programme (PEP) at the School of Engineering, University of Cádiz, initiated in 2012 as a by-product of the PEP previously started at the School of Education (Rubio Cuenca \& Domínguez, 2016). The idea of developing a PEP for the School of Engineering is a response to the communication needs of a globalized society in which information and communication come in many formats and contexts, especially when it comes to the academic and professional context of engineering. In this sense, the PEP's main objective is the improvement of language skills of students working in Spanish and English ('the language of Engineering'). Both teachers and staff at the School of Engineering are very engaged with educational innovation in general. As hosts of the 2016 CUIEET (Congreso Universitario de Innovación Educativa en las Enseñanzas Técnicas) they invited Plácido Bazo Martínez (coordinator of the CRUE's Sub-commission for Internationalization and Cooperation) to give the opening plenary: a Linguistic Policy for $21^{\text {st }}$ century Engineers.

With the development of a PEP, the School of Engineering is contributing on at least three levels: by furthering the internationalization of the University of Cádiz, through the promotion of international mobility for outgoing and incoming students and teachers; by providing continuity for the students who are coming (in increasing numbers) from bilingual secondary education and, not least, regarding the general requirement for students to certify a minimum level (in line with the CEFR) in a European language to obtain graduation certificates and diplomas.

The teaching and awareness of English in and for Engineering amongst teaching staff at the School of Engineering in Cádiz has experienced an exponential development in the last 30 years, going from content teachers compiling lists of technical terms in English (without any planning or coordination), to specific/technical English taught by a language specialist (since the beginning of the 90s). New trends in English for Specific Purposes (ESP) at the time (e.g. Huckin \& Olsen, 1983; Hutchinson \& Waters, 1987) were gradually adopted according to learner needs. The 2010s (with language policy regulations issued at the University mentioning CLIL for the first time in an official document) have seen significant changes in how we view language learning and acquisition. ESP courses are now more content-oriented and are increasingly becoming subsidiary to content subjects taught through a foreign language. ESP specialists are starting to coordinate the contents of their courses with content teachers, and language and content, at least in the School of Engineering, is increasingly integrated.

\section{Methodology and Participants}

The teachers involved in the PEP are all participating on a voluntary basis, which of course signals interest and motivation. In line with Lortie's (1975) "apprenticeships of observation", teachers are likely to be influenced by their own previous experiences as learners (see also Flores \& Day, 2006). Discussion confirmed that the teachers in our study had little, if any, experience as students in bilingual/other language content classrooms. Teacher development within the PEP has therefore been based on two key goals: language reinforcement and the 
introduction and development of new 'language aware' teaching strategies. This is in line with research into student outcomes in university bilingual classes, suggesting that attention to language is necessary if linguistic gains are on the agenda (Aguilar \& Muñoz, 2013; Ament \& Perez Vidal, 2015).

The data we present here comes from two teacher development sessions (conducted in 2015 and 2017) and consists of two sets of teacher reflections (written) - one from each session. During the first session, teachers participated in a translanguaging activity, designed to give them experience with planned use of the L1 in the bilingual classroom (while also providing us with data). In small, self-selected groups of two to four, they were presented with a series of prompts and instructed to first translate them into and discuss them in Spanish before drafting a 'reaction' in English. Their reactions were composed, collaboratively in their groups, on screen and e-mailed anonymously to us at the end of the session along with demographic information via Survey Monkey. We then classified the responses into four categories: Agree/Disagree/Neither/Vague. In many cases, the whole group either agreed or disagreed with the prompt; at times, however, the group as a whole did not agree and told us so (thus Neither). On a couple of occasions, the responses were rather vague, and we were not confident enough to align them with any particular attitude. See Appendix for a breakdown of responses to each prompt.

In the second session, a reduced number of teachers (12) participated in a round-table debate during which we re-visited some of the findings from the previous session and discussed some of the questions they had thrown up. At the end of the session they were given fifteen minutes to write a text (by hand) telling us 'where they thought they were and where they thought they were going'. All but one of the teachers in the second session were also present in the first. In both sessions the teacher reflections were submitted anonymously. This prevents comparison of individual attitudes and thus the discussion of the results below is largely qualitative.

Apart from two from the Business department, the teachers were involved in a range of Engineering, Information Technology (IT) and science-related subjects: Aerospace Engineering (1); Applied Mathematics (1); Biomedical engineering (1); Chemistry (1); Computation (3); Computer Architecture (2); Computer Science (4); Design Methodology (1); Electrical Engineering (1); Image Processing (1); Information Technology (2); Operating Systems (2); Physics (1) and Software Engineering (3). Most of them were teaching in the Computer Science Degree, but other degrees are involved to a lesser extent, such as Aerospace Engineering, Industrial Technology Engineering, Design and Product Development Engineering, and Masters in Computing Engineering and IT Security.

The group of respondents comprised 15 men and 11 women; aged between 28 and 56 (mean age 43.9); with from one to twenty-nine years of university teaching experience (average length of service 14.5 years). The age at which most of them became university teachers suggests that career academics dominate. Many of them started teaching in their mid-twenties (average 26.6) - presumably during or shortly after doctoral studies. Eleven of the teachers were already involved in bilingual teaching, ten had committed themselves to it in the next term and five were interested in the possibility and wanted to find out more. All were Spanish L1 speakers and, although we can see a cluster around B2, English levels 
were heterogeneous, ranging from A2 (participants who openly declared they were doing this training as much for their English as for their teaching) to a certified C2. One respondent did not answer. We should point out that the teachers who were already in the programme were all at $\mathrm{B} 2$ or higher.

Table 1. Teacher English Levels

\begin{tabular}{|c|c|c|c|}
\cline { 2 - 4 } \multicolumn{1}{c|}{} & $\mathrm{M}$ & $\mathrm{W}$ & TOTAL \\
\hline $\mathrm{A} 2$ & 1 & 1 & 2 \\
\hline $\mathrm{B} 1$ & 2 & 5 & 7 \\
\hline $\mathrm{B} 2$ & 8 & 3 & 11 \\
\hline $\mathrm{C} 1$ & 2 & 2 & 4 \\
\hline $\mathrm{C} 2$ & 1 & 0 & 1 \\
\hline
\end{tabular}

\section{Results AND Discussion}

At this stage in our research, we are looking at the teacher attitudes from three perspectives: we are trying to better understand what they think about language in their 'normal' i.e. Spanish/monolingual teaching; what they think about the learning process in itself and what they think about bilingual classrooms. These are, of course, enormous questions. This is very much an exploratory study: Rather than looking for answers, we are still only fine-tuning our questions.

\subsection{Teacher attitudes regarding L1/monolingual learning}

On the assumption that the more we knew about how they operated when teaching in 'normal' classes (i.e. in Spanish), the more we would be able to help their transition to L2, we began by asking them about L1 praxis. We first asked to what extent they thought monolingualism was the norm in European university classrooms (see Appendix, prompt 1). The range of responses was quite diverse and seemed to indicate that 'monolingualism' was not a concept to which the teachers devoted that much attention. Of course, there is a potential double entendre to 'monolingual'. We glossed it as 'everyone shares the same L1', but it could equally be interpreted as no-one in the class speaks more than one language. Or even as 'everyone in the class speaks the same language, the first and only language they ever learnt'. Since we assume that 21 st century university students have at least some knowledge of other language(s), we were trying to focus on shared L1.

One group defended L1 monolingualism: "We think it is usual, because normally people are more comfortable in their mother tongue, and it is easy to learn new concepts in L1."; another group was pro-monolingual but open to it being an L2: "Even universities with international students, they choose only one. This language doesn't have to be the native language." However, many of the teachers interpreted the question more from a Medium of Instruction perspective: "The majority of the European universities offer their degrees, especially master's degrees, in English. The reason for this is double: first, because they attract more students from the international market, and second, because they help their students develop their English language skills for their professional world." 
Teachers also acknowledged sociolinguistic factors, pointing out that Europe contains multilingual regions. For example: "In some countries with multiple official languages, many groups of students have some language diversity." Others were more geographically positioned, for example "[F]rom my experience in other countries, for example, Denmark, Norway, and so on... courses were given in English."; and one group observed that monolingualism "occurs especially in southern European universities."

Despite a general (European-led) move towards competence-based teaching and assessment, and the fact that one of the key competences is 'linguistic', there is a tendency in Spain to group technical and scientific subjects under the banner of Áreas No-Lingüísticas (ANL). At the very least, this belittles the importance of language in learning. To an applied linguist, language is incontrovertibly core to the endeavour, but should we be surprised if science and technology teachers do not subscribe to the same view? According to Halliday (2004: 78), when asked to consider their subject from a linguistic perspective, most science teachers tend to conceptualise the question of language from the perspective of vocabulary (jargon) rather than grammar. Aguilar (2017) found a similar view regarding glossaries amongst Spanish engineering lecturers undertaking EMI. When interviewing Swedish physics lecturers, Airey (2012) found that although they all agreed that teaching language per se was not part of their remit they did feel that it was their responsibility to help students become more fluent in the 'language of mathematics', in other words to develop disciplinary discourse. So, we asked the teachers whether they considered language when they are teaching in Spanish and how important they thought general language abilities were in learning (see Appendix, prompt 2).

The fact that most of the participants in the activity had already had some training in bilingual teaching methodology likely influenced their perceptions, rendering them more language aware than subject-matter teachers with no specific bilingual training (on this point see also Dafouz, Hüttner and Smit, 2016: 128). A few of the groups still felt that language is less important in their content domain: "We believe that the relevance of the language abilities depends on the subject. In technical studies that is less than other studies." or "We are more interested in learning the subject than the correct use of the language." That said, most of the groups recognized the importance of language: "Language abilities allow students to understand what they are taught and asked, so students lacking in these abilities take much longer to learn a subject and solve a problem only because it's hard for them to understand the explanations and questions." Nonetheless, and in line with Airey's (2012) observation that teachers would be unlikely to correct student language errors, several groups appeared to sidestep responsibility for the language side of things: "We think that these abilities are very important, but the teachers suppose that students already have these abilities and they are not taken into account in the learning process."; "the professor is not responsible for things such as grammar mistakes."

When prompted about the issue of teaching new terminology (see Appendix, prompt 3), most of the groups agreed that this issue should be a priority for content teachers: "The specific terms used in a subject should be introduced by the teacher of that subject." "In L1 learning, teachers are responsible for new terminologies." However, two groups viewed content teachers as models and responsible for correct language use in the subject matter they teach: "The teachers of any subject also have to teach their students generic competences, such as oral and written expression."; "Lecturers are not only responsible for teaching terminology but also for using the language correctly and making precise statements." Finally, there was 
one group who saw content teachers as language facilitators: “...the teacher can also help the students improve their language skills." In conclusion, although the main responsibility of content teachers is teaching content, they believe they are also responsible for both teaching terminology and, to a lesser extent, serving as a model for correct use of their L1 together with teaching and/or helping students with specific language skills.

One of the declared aims of the CRUE guidelines mentioned above (published after the session we are discussing), proposed under the heading of 'student training', is to "improve[s] university students' communication skills both in the mother tongue (L1) and in the foreign language (L2)" (2017: 7, our italics). We take this as confirmation that we were right to want to factor L1 into the equation. Our reading of related research suggests that the adoption of L2 teaching could be fuelling a general re-evaluation of language across the curriculum (LAC) at tertiary levels (see for example Airey, 2012; Hughes, 2016). Along those lines, Airey et al. (2017: 17) argue that

teachers should be able to motivate the language choice in the courses they teach, describe the (linguistic) skills that are cultivated and detail how these skills are developed and assessed. Moreover, there should be a clear understanding of how the skills developed in a particular course relate to the overall goal-the development of disciplinary literate graduates.

\subsection{Teacher attitudes regarding learning in general}

Content teachers are probably not used to thinking about language from a skills perspective, although since all the teachers involved have some form of FL certification, they will have done exams which were delineated by skills. We asked whether they thought any of the skills were more important than the others (see Appendix, prompt 4). During discussion, several groups asked about the difference between skills and competences, thereby suggesting that they are thinking about the move away from fact-based and towards competence-based praxis. The mediator downplayed conceptual differences.

Hyland (2013: 69) convincingly argues that writing is the backbone of academic development: "We are what we write, and we need to understand the distinctive ways our disciplines have of identifying issues, asking questions, addressing a literature, criticising colleagues and presenting arguments". That said, none of the respondents opted for writing. Approximately half of them felt that all four skills were equally important, and several pointed out that different skills will be more important at different moments: "We cannot select an option since we think that all of them have the same importance. It depends on the task we are doing". One group opted for reading but did not provide any justification.

As part of the ongoing development process, these teachers are being encouraged to reconsider traditional teacher-fronted monologic teaching modes and to experiment with cooperative, collaborative and dialogic modes. This is partly fuelled by the fact that research has pinpointed a series of potential problems with lecturing in an L2, ranging from a selfassessed lack of fluency (Aguilar, 2017), to a reduced use of pragmatic strategies (Björkman, 2011) and meta-discursive devices (Dafouz \& Nuñez Perucha, 2010). It also conflates with a tendency in the sciences to promote argument and discussion as paths to learning (e.g. 
Jonassen \& Kim, 2010; Phelps Walker \& Sampson, 2013). It was therefore interesting that four of the pairs felt that listening and speaking were more important "speaking and listening are more difficult to learn but maybe more useful to communicate with other people."

Talking about skills led us to the question of input and output (see Appendix, prompt 5). From a simplistic perspective, the distinction could be interpreted as a contrast between teacher-centred (input) and student-centred (output) approaches, but most of the teachers interpreted it more literally. Some of the groups took a pragmatic stance: "the information that they receive is more important than what they produce, because if initial information is wrong the results will be bad."; "To produce information about some topic, we think that first it is necessary to learn or receive information from some source."

Three groups opted for output: "We think it is more important what they are capable to produce than what they receive." One pair went a step further by asserting that without output there can be no feedback "which is essential in learning." A couple of the groups placed more emphasis on the gloss of input in parenthesis in the prompt - the information they receive - with a defence of self-directed learning and the value of students looking for their own information. "In fact, we think that teachers should provide less input so that students are encouraged to find out on their own."

\subsection{Teacher attitudes to bilingual learning/classrooms}

Regarding the content and language mix, and the importance accorded to each (see Appendix, prompt 6), the teachers naturally lean towards content as their main priority, but most are also thinking about language: "We are not language teachers. We use both languages (L1 or L2) to teach concepts related with the subject we teach. So, the content is more important than the language."; "The subject of the course is more important than the language, even if it is taught in a second language."; "Content is more important than language, as you have to develop the professional skills of your career. Language is a plus."

There were also people who insisted on full integration - a 50/50 approach. A variety of reasons were proffered. From the perspective of student need, for example: "Both the content and the language are important since students need to know the meaning of the words as well as the content of the course." One group stated: "When students chose bilingual learning, they expect to learn both, contents and language." In some cases, it was clear that language = languageS, that the teachers were also factoring L1 into the picture: "the student must learn the topic in their native language." and also from a more conceptual viewpoint: "If it is truly bilingual then both should be equally important."

Research into English-taught programmes has flagged a lack of heterogeneity amongst participants as a key problem (Strotmann et al., 2014: 96; Wächter \& Maiworm, 2014: 22), but the Cadiz teachers were not as worried about mixed levels as they were about low levels. This echoes findings from two other Spanish studies: Doiz, Lasagabaster \& Sierra (2011) and Fortanet-Goméz (2012), both of which found that teachers felt that low L2 competence amongst their students was hindering their progress. There did seem to be a feeling among the teachers that some students were applying a 'two birds, one stone' approach to content in English in the belief that signing up for bilingual classes would, in itself, magically transport them to the B1 they know they are going to need in order to 
graduate, and that this could be counter-productive. In general, however, the teachers did not see mixed levels as problematic; in fact, they expected them and were learning to deal with them. They discussed grouping students to favour peer learning and some appeared to appreciate that the negotiation of meaning between groups made up of mixed levels could contribute to the development of communicative skills "it is more important to be open to listen to and understand people with more or less L2 levels." About half of them idealized the teacher having a higher level of L2 competence than the students. At some level, then, they also see themselves as 'model' L2 users, and indeed have been encouraged to do so during the training programme.

If all the students in a classroom are locals, and they share a language other than the stipulated Medium of Instruction, unless there are strict prohibitions, it is logical and inevitable that this other language will come into play. Research in supposedly L2 monolingual settings has repeatedly found classroom practice which subverts medium of instruction norms and 'allows' L1 (for example in EMI, Doiz \& Lasagabaster, 2017; in CLIL, Moore \& Nikula, 2016; and in EFL, Storch \& Wigglesworth, 2003). The feeling amongst the teachers seemed to be that while an English-only policy might be feasible in an EMI-type setting, with the proviso that all the participants be at a high level, that did not reflect their reality.

Underlining the fact that there are diverse potential approaches, and that each implies a range of decisions (on this point see also Aguilar and Muñoz, 2013), teachers were presented with, and we discussed, a heuristic model outlining a continuum of (university) bilingual teaching ranging from EMI to EFL as set out in the Figure 1. At either end of the continuum we present 'hard-line' (supposedly) English-only options: EMI as English-only content teaching and EFL as English-only Foreign Language teaching. We also included English for Specific Purposes (ESP) and English for Academic Purposes (EAP) since, as Ament and Pérez Vidal (2015: 51) argue, they can be interpreted as primary moves in the internationalization of higher education.

Regarding a 'name' for an approach which explicitly integrates content and language, we have struggled with a decision between CLIL (Content and Language Integrated Learning) and ICLHE (Integrating Content and Language in Higher Education) (See Rubio-Alcalá $\&$ Moore, this volume). CLIL is largely associated with primary and secondary education and we wanted to emphasize the contextual difference and so in the figure we use ICLHE.

Figure 1. Continuum of Tertiary Bilingual Education

\begin{tabular}{|lllll|}
\hline L2 monolingual & Bilingual & & L2 monolingual \\
content-focused & & & & \\
EMI & (weak) ICLHE & (strong) ICLHE & ESP/EAP & EFL \\
\hline
\end{tabular}


This distinction rests on the role accorded to the L1 in the process. While EMI at one end and ESP/EAP/EFL at the other are conceptualized, in theory at least, as English-only, ICLHE is taken to factor the L1 into the equation. We suggest that Strong ICLHE implies attention to both languages, and the use of the L1 as a 'resource', whereas weak ICLHE will lean on L1 when necessary but not explicitly plan for it, in other words the L1 is understood as 'recourse'. Doiz \& Lasagabaster (2017: 169) found that teachers in EMI settings will turn to the L1 as a recourse, "when a breach in comprehension is feared or has already occurred" but that they may feel guilty about doing so; our goal was to 'normalize' the behaviour as a recognised strategy. Research has found that asking learners to engage with cognitively challenging material without recourse to their L1 can impede learning (Storch \& Wigglesworth, 2003) and if that is true in EFL classrooms, it is probably even more so in L2 content classes.

As part of the follow-up questionnaire conducted at the end of the first session, teachers were asked to position themselves (and their teaching) on the continuum (EMI $\leftrightarrow$ EFL). They were also asked to clarify their position regarding use of language in the classroom via a multiple-choice option a) only in English; b) mostly in English c) both languages. We present the results in Table 2 below. There are obvious inconsistencies here (for example EMI and Weak ICLHE with both languages; Strong ICHLE and mostly L2) but, in fact, these results proved extremely useful in planning subsequent steps.

Table 2. Correlation between positions on the continuum and beliefs regarding use of languages

\begin{tabular}{|c|c|c|}
\hline STANCE on the continuum & \multicolumn{2}{|c|}{ Use of Languages } \\
\cline { 2 - 3 } & Both & Mostly L2 \\
\hline EMI & 1 & 2 \\
\hline Weak ICHLE & 14 & 5 \\
\hline Strong ICHLE & 1 & 3 \\
\hline
\end{tabular}

We could see that, while teachers seemed open to some form of bilingual Integrated Content and Language approach (rather than the monolingual L2 approach implied by EMI), they were still unclear regarding the whys and wherefores of Spanish use in their classrooms. In order to go deeper, in the second session in 2017, we organized a roundtable discussion on the use of the L1 in bilingual classrooms. At the outset, we revisited the results of the previous surveys reported on above and tried to untangle fuzziness around the use of language question. It emerged that the problem was largely language-related. There was a terminology problem: While in English we can make the tidy distinction between the L1 as 'recourse' or 'resource', in Spanish both can be translated as recurso, and so it had been difficult for teachers to process the distinction. This was coupled with the fact that previous discussion of the heuristic had perhaps been too perfunctory (reminding us that we are language specialists, and they are not). 
Overall the teachers accepted that both languages did need to be involved. Around half of them felt that if the whole idea was to teach through English, English had to take precedence. Amongst those who opted for Weak ICLHE, opinions regarding Spanish ranged from using it as a quick fix in times of need, to restricting it to scaffolding in the presentation of more complicated ideas (thereby reducing the cognitive load). Several acknowledged a possible value in more proactive bilingualism but declared themselves hampered by time constraints. Other research has flagged this as a problem (Aguilar, 2017; Strotmann et al., 2014). The other half were more open to the idea of Strong ICLHE: explicitly bilingual classroom practice: "I can see I'm progressing from using L1 as a recourse to using it as a resource, with an intentional and planned used in the class."; "To my mind in bilingual teaching is important to use both languages L1 and L2 because students must have the skill of using both languages in different contexts: academic, work and normal use."

\section{Conclusions}

To be able to appreciate the real value of our findings, it is essential to take the specific context into account. The Plurilingual Education Programme of the School of Engineering at the University of Cádiz, is shaped by the fact that (at the moment at least) the majority of students signing up for bilingual programmes are locals with limited L2 expertise and thus the approach favoured is to integrate content and language, using both L1 and L2 as resources for lesson planning and implementation. We interpret this as an example of Internationalization at Home.

The starting point for this research was a translanguaging activity - planned use of both languages during a teacher development workshop on bilingual education, intended as a model activity which teachers could use in class. In essence, it was an opinion gap activity: Participants were asked to give their opinions about L1 learning, learning in general and bilingual learning. During a second session, the findings of the previous activity were debated.

Regarding L1 learning, we realized that, as opposed to language specialists, the different groups had only a vague notion of key terms such as L1 and monolingualism, which correlates with the tendency in Spain to group science disciplines under the banner of nonlinguistic areas. However, when prompted about language abilities in learning, they proved to be more language aware than other colleagues with no specific bilingual training. Most averred both that contents prevail over language and that content teachers are not language teachers. Nonetheless, they felt that all teachers should serve as models and be responsible for the correct use of language in general, be it the L1 or a L2. In general, the teachers did not see mixed levels as problematic although they did worry about student L2 levels and considered fostering mixed-level groupings as a strategy for developing communicative skills. When asked to position themselves on a continuum between EMI and EFL, we could see that, while teachers are open to some form of bilingual Integrated Content and Language approach (i.e. strong vs. weak ICLHE), they are still working towards an understanding of Spanish use in their classrooms. This points the way for our continuing efforts. 


\section{REFERENCES}

Aguilar, M. (2017). Engineering lecturers' views on CLIL and EMI. International Journal of Bilingual Education and Bilingualism, 20(6), 722-735.

Aguilar, M. \& Muñoz, C. (2013). The effect of proficiency on CLIL benefits in Engineering students in Spain. International Journal of Applied Linguistics, 24(1), 1-18.

Airey, J. (2012). 'I don't teach English': The linguistic attitudes of physics lecturers in Sweden. AILA Review, 25, 64-79.

Airey, J.; Lauridsen, K.M.; Räsänen, A.; Salö, L., \& Schwach, V. (2017). The expansion of English-medium instruction in the Nordic countries: Can top-down university language policies encourage bottom-up disciplinary literacy goals? Higher Education, 73(4), 561-576.

Ament, J.R. \& Pérez Vidal, C. (2015). Linguistic outcomes of English medium instruction programmes in higher education: A study on economics undergraduates at a Catalan university.Higher Learning Research Communications, 5(1), 47-68.

Björkman, B. (2011). Pragmatic strategies in English as an academic lingua franca: Ways of achieving communicative effectiveness? Journal of Pragmatics, 43(4), 950-964.

CRUE (2017). Documento Marco de Política Lingüística para La Internacionalización del Sistema Universitario Español. Madrid: CRUE.

Dafouz, E.; Hüttner, J., \& Smit. U. (2016). University Teachers' Beliefs of Language and Content Integration, in T. Nikula, E. Dafouz, P. Moore \& U. Smit (Eds.) Conceptualising Integration in CLIL and Multilingual Education (pp.123-144). Clevedon: Multilingual Matters.

Dafouz, E. \& Núñez Perucha, B. (2010). Metadiscursive devices in university lectures: a contrastive analysis of L1 and L2 teacher performance, in C. Dalton-Puffer, T. Nikula \& U. Smit (Eds.), Language Use and Language Learning in CLIL Classrooms (pp. 213-231). Amsterdam: John Benjamins.

Doiz, A. \& Lasagabaster, D. (2017). Teachers' beliefs about translanguaging practices, in C.M. Mazak and K.S. Carroll (Eds.) Translanguaging in higher education: Beyond monolingual ideologies (pp. 155-175). Clevedon: Multilingual Matters.

Doiz, A.; Lasagabaster, D., \& Sierra, J.M. (2011). Internationalisation, multilingualism and Englishmedium instruction: the teachers' perspective. World Englishes 30, 345-359.

European Commission (2015). Erasmus Facts, Figures \& Trends. Available from: http://ec.europa.eu/ dgs/education_culture/repository/education/library/statistics/erasmus-plus-facts-figures_en.pdf , accessed 8 January, 2018.

Flores, M.A. \& Day, C. (2006). Contexts which shape and reshape new teachers' identities: a multi-perspective study. Teaching and Teacher Education 22(2), 219-232.

Fortanet-Gomez, I. (2012). Academics' beliefs about language use and proficiency in Spanish multilingual higher education. AILA Review 25, 48-63.

Halliday, M.A.K. (2004). Some grammatical problems in scientific English, in C. Coffin; A. Hewings and K. O’Halloran (Eds.) Applying English Grammar, (pp. 77-94). London: The Open University.

Huckin, T.N. \& Olsen, L.A. (1983). English for Science and Technology. A Handbook for Nonnative Speakers. New York: McGraw-Hill Book Company. 
Hughes, N. (2016). We're all language teachers now: teaching subject discipline content through the medium of a second language, in C. Goria, O. Speicher, \& S. Stollhans (Eds), Innovative language teaching and learning at university: enhancing participation and collaboration, (pp. 131-137). Dublin: Research-publishing.net.

Hutchinson, T. \& Waters, A. (1987). English for Specific Purposes. A learning-centered approach. Cambridge: Cambridge University Press.

Hyland, K. (2013). Writing in the University: education, knowledge and reputation. Language Teaching 46(1), 53-70.

Jonassen, D.H. \& Kim, B. (2010). Arguing to learn and learning to argue: design justifications and guidelines. Educational Technology: Research and Development 58(4), 439-457.

Lortie, D. (1975). Schoolteacher: A sociological study. Chicago, IL: The University of Chicago Press.

Moore, P. \& Nikula, T. (2016). Translanguaging in CLIL, in T. Nikula, E. Dafouz, P. Moore and U. Smit (Eds.) Conceptualising Integration in CLIL and Multilingual Education (pp. 211-234). Clevedon: Multilingual Matters.

Olivella Nadal, J. (2016). España como destino de estudiantes universitarios internacionales: datos y tendencias. Working Paper. Universitat Politècnica de Catalunya. Available from http://upcommons.upc.edu/handle/2117/82472_accessed 18 January 2018.

Phelps Walker, J. \& Sampson, V. (2013). Learning to Argue and Arguing to Learn: argumentdriven inquiry as a way to help undergraduate chemistry students learn how to construct arguments and engage in argumentation during a laboratory course. Journal of Research in Science Teaching 50(5), 561-596.

Rubio Cuenca, F. \& Domínguez, J.J. (2016). El programa de enseñanza bilingüe de la Escuela Superior de Ingeniería: Aspectos organizativos, estructurales y metodológicos. Actas de las Jornadas de Innovación Docente de la Universidad de Cádiz, (pp. 78-82). Cádiz: Servicio de Publicaciones de la UCA.

Storch, N. \& Wigglesworth, J. (2003). Is there a role for the use of the L1 in an L2 setting? TESOL Quarterly, 4, 760-770.

Strotmann, B.; Bamond, V.; Lopez Lago, J.M.; Bailen, M.; Bonilla, S., \& Montesinos, F. (2014). Improving bilingual higher education: training university professors in Content and Language Integrated Learning. Higher Learning Research Communications 4(1), 91-97.

Wächter, B. \& Maiworm, F. (2014). English-Taught Programmes in European Higher Education. The state of play in 2014. Bonn: Lemmens. 


\section{Appendix}

\section{TRANSLANGUAGING ACTIVITY -Results}

Note that the 26 participants were organized into ten groups. The data consists of written reflections (not a questionnaire) and the figures below represent group consensus (or not).

\section{Teacher attitudes regarding $\mathrm{L} 1 /$ monolingual learning}

\begin{tabular}{|l|c|c|c|c|}
\hline Prompts & Agree & Disagree & Neither & Vague \\
\hline $\begin{array}{l}\text { 1 In most European universities classes are mono- } \\
\text { lingual (i.e. Everyone shares the same L1) }\end{array}$ & 5 & 2 & 2 & 1 \\
\hline $\begin{array}{l}\text { 2 In L1 (monolingual) learning a student's lan- } \\
\text { guage abilities are largely irrelevant. }\end{array}$ & 1 & 7 & 1 & 1 \\
\hline $\begin{array}{l}\text { 3 In L1 learning, the only language a content } \\
\text { teacher is responsible for is teaching students new } \\
\text { terminologies (associated with their subject). }\end{array}$ & 6 & 4 & 0 & 0 \\
\hline
\end{tabular}

Teacher attitudes regarding learning in general

\begin{tabular}{|l|c|c|c|c|}
\hline Prompts & Agree & Disagree & Neither & Vague \\
\hline $\begin{array}{l}\text { 4 In learning in general, there is at least one lan- } \\
\text { guage skill (speaking / writing / reading / listen- } \\
\text { ing) which is the most important. }\end{array}$ & 4 & 6 & 0 & 0 \\
\hline $\begin{array}{l}5 \text { In learning in general, as far as students are } \\
\text { concerned, the input (the information they re- } \\
\text { ceive) is more important than the output (what } \\
\text { they produce) }\end{array}$ & 2 & 8 & 0 & 0 \\
\hline
\end{tabular}

Teacher attitudes regarding $\mathrm{L} 2 /$ bilingual learning

\begin{tabular}{|l|c|c|c|c|}
\hline Prompts & Agree & Disagree & Neither & Vague \\
\hline $\begin{array}{l}\text { 6 In bilingual learning, the content is more impor- } \\
\text { tant than the language. }\end{array}$ & 6 & 4 & 0 & 0 \\
\hline $\begin{array}{l}\text { 7 In a bilingual classroom, it is important that } \\
\text { everyone in the classroom (including the teacher) } \\
\text { have the same L2 level. }\end{array}$ & 2 & 7 & 1 & 0 \\
\hline $\begin{array}{l}\text { 8 A bilingual classroom should operate a strict L2 } \\
\text { only policy. }\end{array}$ & 0 & 9 & 1 & 0 \\
\hline
\end{tabular}

